\title{
Konstruksi Identitas Global Dan Lokal Dalam Majalah Gogirl!: Sebuah Hibriditas (Analisis Semiotik Majalah Gogirl! Edisi 101 Bulan Juni Tahun 2013)
}

\author{
Mediana Utami \\ Program Studi Ilmu Komunikasi, Universitas Muhammadiyah Yogyakarta, Yogyakarta, \\ Indonesia. \\ Email:medianatami@gmail.com \\ Muria Endah Sokowati \\ Program Studi Ilmu Komunikasi, Universitas Muhammadiyah Yogyakarta, Yogyakarta, \\ Indonesia. \\ Email:muriaendah@umy.ac.id \\ (corresponding author)
}

\section{Article Info}

Article History

Received 23 Nov 2020

Revised 23 Feb 2021

Accepted 18 March 2021

\begin{abstract}
This research focuses on describe the position of local and global identities in hybridity. In explain the construction of local and global identities on Gogirl!, the author used semiotics of Roland Barthes. Hybridity is a resistance of local culture to global domination. Magazine assimilated the elements of global culture, devoid eliminated or defend the local elements. In this case, there are certain hybridity mechanisms that has been done, namely the use of hodgepodge language, a blend of English and bahasa Indonesia; the usage of western elements as inspiration; and maintaining the spirit of localism. The hibridity of GoGirls! is a form of negotiation to provide opportunity on the present of local identity. As an inferior subject, local identity becomes an active subject in expressing its identity at the global level through hybridity.
\end{abstract}

Keywords: hybrid culture, hibridity, global culture, local culture, magazine

\begin{abstract}
Abstrak. Penelitian ini berfokus pada bagaimana posisi identitas lokal dan global dalam hibriditas. Melalui analisis semiotik Roland Barthes, artikel ini menjelaskan konstruksi identitas lokal dan global yang direpresentasikan dalam majalah Gogirl!. Hibriditas merupakan perlawanan dari budaya lokal terhadap dominasi global. Dalam kaitan ini, majalah menerima unsur budaya global tanpa menghilangkan atau mempertahankan unsur lokal. Di sini, ada beberapa mekanisme hibriditas yang dilakukan, seperti penggunaan bahasa gado-gado, campuran bahasa Inggris dengan bahasa Indonesia; menggunakan elemen barat sebagai inspirasi; dan menjaga semangat lokalisme. Hibriditas yang dilakukan oleh Majalah Gogirl! adalah bentuk negosiasi untuk memberikan kesempatan menampilkan identitas lokal. Sebagai subjek yang "terjajah" atau inferior, identitas lokal menjadi subjek yang aktif dalam mengekspresikan identitasnya di tingkat global melalui hibriditas
\end{abstract}

Kata kunci: budaya hibrid, hibriditas, budaya global, budaya lokal, majalah 


\section{PENDAHULUAN}

Media sudah menjadi bagian tak terpisahkan dalam kehidupan sosial masyarakat modern. Dalam hal ini, media digunakan untuk memerdalam pengetahuan serta mengetahui berbagai informasi terkini sehingga media dapat memengaruhi bagaimana setiap individu memahami suatu realitas sosial (Ida, 2014). Namun, realitas yang hadir dalam media bukanlah realitas objektif, tapi hasil konstruksi. Seperti identitas budaya, konstruksi yang terbentuk akan selalu berubah karena realitas yang dituliskan tidak pernah tetap. Ini juga berlaku dalam majalah, utamanya majalah yang menyajikan gaya hidup.

Gaya hidup terkini menjadi isu utama yang ditampilkan oleh mayoritas majalah remaja. Majalah merupakan salah satu inspirasi bagi sebagian remaja Indonesia dalam membentuk gaya hidup mereka. Usman (2006) menjelaskan bahwa remaja memilih majalah berdasarkan pada informasi yang diberikan sesuai dengan kecenderungan saat itu. Gaya hidup, fashion, selebriti, kecantikan, kehidupan personal atau percintaan dan teknologi adalah beberapa contoh isi rubrik yang terdapat dalam majalah remaja di Indonesia. Tidak berbeda dengan majalah tersebut, majalah remaja Gogirl! yang menjadi fokus penelitian ini juga menempatkan gaya hidup remaja menjadi materi utama rubrik.

Fenomena majalah Gogirl! menarik terutama jika dikaitkan dengan globalisasi. Ini karena globalisasi mengakibatkan berbagai elemen budaya luar masuk ke Indonesia. Penggunaan media menjadi penghubung tanpa batas dalam menyalurkan identitas budaya global dari negara-negara yang memiliki posisi dominan. Negara-negara berposisi dominan ditandai dengan kemampuannya yang luas untuk memberikan pengaruh atau memproyeksikan kekuasaannya dalam skala global. Amerika Serikat dan negara-negara Eropa, seperti Inggris, Jerman, dan Prancis untuk menyebut beberapa contoh.

Negara-negara tersebut mencoba mengekspor identitas mereka, dan menyebarluaskan ke seluruh dunia sebagai identitas global yang dikonsumsi masyarakat dunia. Merujuk mubah (2015), negara-negara maju merupakan aktor utama dalam proses globalisasi yang selama ini berlangsung. Mereka memiliki power dalam proses globalisasi. Negaranegara tersebut menguasai teknologi informasi dan komunikasi sehingga memudahkan mereka menyebarkan nilainilai global.

Sebagai bagian dari masyarakat global, Indonesia tidak dapat menahan budaya asing yang masuk. Batas-batas kedaulatan negara tidak mampu menahan masuknya budaya dari negara lain meskipun budaya itu memiliki perbedaan besar (Mubah, 2015). Sebaliknya, budaya global yang masuk secara perlahan diterima masyarakat. Globalisasi mengakibatkan masyarakat mengonsumsi budaya negara-negara dominan yang nyaris seragam atau homogen. Ritzer (2006) berpendapat bahwa keunggulan lokal akan cenderung berhubungan dengan heterogenitas, sementara dominasi global akan lebih dihubungkan dengan homogenisasi. Meskipun demikian, bersifat homogen tidak mengartikan bahwa budaya terdahulu, yaitu lokal sepenuhnya hilang. Sebaliknya, ada banyak interaksi di antara global dan lokal. Globalisasi memang memengaruhi bagaimana representasi budaya lokal, tapi masyarakat juga mempunyai berbagai cara untuk mempertahankan budaya lokal. Salah satunya dengan cara membentuk 
suatu hybrid culture antara budaya lokal dengan budaya global.

Budaya global atau nilai-nilai kebudayaan luar menjadi dasar dalam pembentukan sub-sub kebudayaan yang berdiri sendiri dengan kebebasankebebasan ekspresi. Sebagian budaya lokal mampu beradaptasi sekaligus bertransformasi dengan perkembangan teknologi yang dibawa oleh globalisasi. Sebagai contoh, di tengah kekhawatiran memudarnya budaya lokal di Indonesia, kesenian tradisional Ketoprak mampu bertahan dengan mempopulerkan kembali kesenian tersebut melalui tayangan televisi yang dimainkan oleh kelompok srimulat (Surahman, 2013).

Salah satu sarana yang membuka pintu masuk budaya-budaya global adalah majalah waralaba dari luar negeri yang membawa identitas budaya luar, khususnya budaya barat ke Indonesia, seperti penggunaan bahasa Inggris sebagai bahasa keseharian, ekspresi gaya fashion ala barat, dan lain sebagainya. Majalah waralaba seperti Cosmogirl, Seventeen, Cleo, dan lainnya kerap memunculkan identitas-identitas tersebut.

Berbeda dengan majalah-majalah yang disebut di atas, majalah Gogirl! adalah majalah produksi Indonesia. Namun dalam kemasannya, tidak berbeda dengan majalah waralaba. Majalah Gogirl! menggunakan sampul depan selebriti luar negeri, dan menggunakan bahasa campuran dalam penulisannya, yaitu bahasa Indonesia dan bahasa Inggris. Kadang kala, diselipkan istilah-istilah gaul khas anak muda zaman sekarang untuk menggambarkan kedekatan dengan pembaca. Tentu saja, ini dilakukan untuk meningkatkan minat pembaca.

\footnotetext{
${ }^{1}$ Istilah "lokal" yang dimaksud adalah yang berasal dari Indonesia, sementara istilah "global" mengacu
}

Dalam setiap edisi, majalah Gogirl! rata-rata memuat 35 rubrik secara berkelanjutan. Dari total rubrik tersebut, terdapat 22 rubrik yang membahas berbagai hal yang merujuk pada isu-isu global, dan 13 rubrik tentang trend dan isu lokal ${ }^{1}$. Isu budaya global berupa rubrik yang membahas informasi selebriti Hollywood, inspirasi gaya fashion yang berkiblat pada mode ala barat, rekomendasi film ataupun lagu berbahasa Inggris, dan lainnya. Isu lokal antara lain pembahasan budaya lokal, informasi peristiwa lokal, styling menggunakan produk serta model lokal, dan sebagainya.

Tema menarik serta konten berita terkini merupakan elemen utama penyajian rubrik majalah Gogirl! ini untuk menarik minat pembaca. Pasalnya, konten yang menarik minat pembaca mayoritas mengacu pada isu-isu barat. Tumanggor \& Ridho (2017) menuliskan,

Produk-produk budaya lokal mulai ditinggalkan lantaran dianggap ketinggalan zaman, tidak up to date, kuno dan semacamnya. Oleh karenanya, generasi terkini dengan basis kulturalnya masing-masing kemudian meski tidak sama, akhirnya memilih untuk mengadopsi budaya baru atau budaya kekinian yang telah berasimilasi dengan budaya barat (hybrid culture).

Berbagai fakta di atas menunjukkan bahwa budaya global mempengaruhi konten majalah Gogirl!. Wacana globalisasi menyebabkan masyarakat secara bersama-sama mengonsumsi budaya global yang sama. Budaya global ini memengaruhi representasi yang ingin dibentuk dalam majalah. Ini menyebabkan munculnya pertemuan antara identitas

pada elemen-elemen kultural yang berasal dari luar, terutama barat. 
global dan lokal, yang dapat ditemukan, misalnya, dalam komentar Nilan dan Feixa berikut.

"Hybridization is a process of cultural interaction between the local and the global, the hagemonic and the subaltern, the centre and the the periphery. On the other hand, hybridization is a process of cultural transactions that reflect how global cultures are assimilated in the locality, and how non-western impact upon the west" (Nilan \& Feixa, 2006).

Hybrid culture terjadi ketika ada pertemuan antara satu budaya dengan budaya lain. Masing-masing budaya memiliki identitasnya sendiri. Globalisasi pada dasarnya dianggap menganggu pembentukan atau justru menyebabkan munculnya identitas budaya ganda, yakni masuknya dua identitas dalam individu yang sama, yaitu budaya global dan budaya lokal (Ibrahim \& Akhmad, 2014). Masuknya dua identitas budaya yang berbeda akan menghasilkan suatu kebudayaan baru. Kedua budaya tersebut bertemu sekaligus bergabung yang pada akhirnya membentuk budaya homogen, heterogen ataupun sepenuhnya terpisah di antara keduanya. Pertemuan tersebut didasari karena adanya keterlibatan dalam proses globalisasi.

Huddart (2006: 7) menyatakan, "In the case of cultural identities, hybridity refers to the fact that cultural are not discrete phenomena, instead they are always in contact with one another and this contact leads to cultural mixed-ness". Dalam konsep hibriditas, budaya satu dengan yang lainnya selalu berhubungan. Ini mengarah pada pencampuran budaya. Bertemunya kedua budaya yang ditampilkan secara bersama dapat dimanfaatkan sebagai suatu strategi untuk memasukkan kepentingan di dalamnya.

Bhabha (1994) menyatakan hibriditas juga disebut dengan konsep liminal atau berada dalam in between dan the third space. Kedua budaya yang bertemu berada dalam suatu ambang yang disebut sebagai liminal atau ruang ketiga. Batas-batas kedua budaya tersebut menjadi melebur sehingga terbentuklah identitas baru sehingga disebut dengan budaya hibrid. Berdasarkan pada proses terbentuknya budaya hibrid, ada nilai serta identitas berbeda yang dibawa oleh masing-masing budaya.

Dalam membentuk suatu identitas baru, budaya lokal yang menempati posisinya sebagai budaya bangsa terjajah meniru budaya global. Bhabha menyebutnya sebagai mimikri. Bhabha mengungkapkan,"Then colonial mimicry is the desire for a reformed, recognizable other, as a subject of a difference that is almost the same, but not quite" (Bhabha, 1994: 86). Bhabha menjelaskan bahwa mimikri merupakan subjek yang berbeda, dan menginginkan menjadi subjek lain yang sama, walaupun pada akhirnya tidak sepenuhnya sama. Dalam hal ini, mimikri merupakan upaya meniru kaum penjajah yang dilakukan oleh masyarakat yang pada dasarnya ditujukan agar memiliki identitas yang sama dengan penjajah tersebut. Selain itu, hal tersebut juga merupakan cara masyarakat menyamar (berkamuflase) untuk bertahan hidup, sekaligus cara untuk mempertahankan budayanya.

The third space menjadi tempat terjadinya suatu hybrid culture melalui proses mimikri. Dalam proses mimikri, tidak sepenuhnya identitas budaya lama hilang, walaupun identitas budaya baru berpengaruh kuat terhadap budaya lama. Setelah terjadinya hybrid culture, identitas baru akan muncul. Hal tersebut menjadi 
dasar bahwa kedua budaya, yaitu budaya lokal dan budaya global berada dalam in between atau the third space.

Melalui penjelasan di atas, majalah Gogirl! dapat disebut sebagai hasil representasi dari hybrid culture yang berlangsung atau juga sebagai produk hybrid culture. Identitas majalah Gogirl! adalah identitas antara identitas budaya global (dalam hal ini budaya barat) yang lebih dominan, dan juga identitas lokal yang tampak dalam berbagai macam tema dalam artikel yang dibahas. Atas argumen ini, penelitian ini berusaha mengetahui lebih mendalam serta melihat bagaimana konstruksi identitas lokal dan global yang dibangun oleh majalah Gogirl!. Peneliti melihat bahwa proses hibriditas dalam majalah Gogirl! merupakan strategi untuk mempertahankan budaya lokal (selain tentu saja demi kepentingan pemasaran). Artinya, proses hibriditas yang berlangsung mampu memberikan ruang secara signifikan pada unsur-unsur lokal.

Proses hibriditas yang progresif bagi budaya lokal sudah banyak diteliti. Inkiriwang \& Inkiriwang (2014), misalnya, menolak pemahaman bahwa hibriditas justru melemahkan kultur lokal. Keduanya menyatakan bahwa lewat konteks Transnational American Studies di Indonesia, dalam media dan budaya organisasi di Indonesia, terjadi hibridisasi. Media dan budaya organisasi ala Amerika cukup banyak mendominasi proses hibridisasi tersebut. Namun, hibridisasi yang berlangsung justru mempercepat kemajuan dalam kedua bidang tersebut. Dengan demikian, riset Inkiriwang dan Inkiriwang justru melihat hibriditas memberikan perkembangan yang positif bagi kultur lokal.

Dukut (2019) juga melihat hibriditas kultural sebagai proses yang progresif. Ia melakukan penelitian tentang kompetensi berbahasa Inggris pada murid di Indonesia dan Jepang. Hibriditas budaya yang mempertemukan budaya lokal dan global dalam TOEFL-Like mobile game application justru bermanfaat dalam meningkatkan kompetensi berbahasa Inggris para siswa. Hibriditas budaya menjadi strategi dalam merancang animasi sehingga memudahkan pengguna untuk belajar bahasa Inggris lewat cara-cara yang inovatif dan menyenangkan.

Demartoto (2020) menganalisis konstruksi identitas dan simbol hibrid sebagai bentuk perlawanan untuk menunjukkan identitas baru, yaitu santri transgender di Pesantren Al-Fatah Yogyakarta. Hasil penelitian tersebut menunjukkan bahwa santri transgender mengubah identitasnya melalui proses hibriditas. Proses mimikri yang terjadi dalam ruang ketiga merupakan ruang negosiasi atas pertarungan budaya dan identitas sehingga identitas baru terbentuk tanpa menghilangkan identitas sebelumnya. Hibriditas terjadi dengan menghadirkan identitas budaya sebagai hasil relasi antara budaya Islam dan budaya transgender. Hadirnya santri transgender merupakan simbol perlawanan terhadap Islam sebagai budaya dominan lewat performa atau simbol yang digunakan sehari-hari untuk menunjukkan identitas baru.

Ketiga penelitian tersebut mendukung asumsi peneliti bahwa majalah Gogirl!-pun melakukan strategi yang sama. Tulisan ini mengungkap apa dan bagaimana majalah Gogirl! menggambarkan realitas dua budaya sehingga membentuk hybrid culture di dalamnya. Selain itu, tulisan ini juga menjelaskan bagaimana unsur negosiasi yang dilakukan majalah Gogirl! dalam artikelnya?

Melalui eksplorasi mendalam atas permasalahan penelitian di atas, penelitian yang terangkum dalam tulisan ini 
diharapkan dapat memberikan kontribusi terhadap kajian-kajian media dan komunikasi yang telah ada dengan memberikan penekanan pada pendekatan budaya yang berperspektif poskolonial. Ini karena pendekatan poskolonial masih belum banyak dipakai dalam kajian media dan komunikasi di Indonesia. Padahal, pendekatan ini sangat penting mengingat Indonesia sebagai negara bekas kolonial yang dalam banyak hal masih terhegemoni oleh ideologi-ideologi kolonial. Untuk itu, perspektif poskolonial dapat dimanfaatkan untuk membongkar praktik-praktik tersebut, terutama yang dilakukan oleh media.

\section{METODE}

Majalah ini akan diteliti menggunakan metode analisis semiotika. Menurut Hidayat (Christomy \& Yuwono, 2004), semiotik merupakan teori dan analisis berbagai tanda (signs) dan pemaknaan (signification). Ini berarti bahwa kehidupan sosial dan budaya sebagai pemaknaan bukan sebagai esensial objek. Analisis semiotik digunakan untuk mengetahui konstruksi budaya lokal dan global yang direpresentasikan teks majalah Gogirl!.

Peneliti menggunakan teknik analisis semiotika Roland Barthes dengan memfokuskan pada tanda-tanda terkait dengan budaya lokal dan global yang terdapat dalam teks di majalah. Metode semiotik Barthes pada dasarnya adalah pengembangan lebih lanjut gagasan Ferdinand de Saussure. Saussure mengatakan bahwa bahasa merupakan sistem tanda yang setiap tandanya memiliki dua bagian, yakni signifier (penanda) adalah citra tanda, seperti yang kita persepsikan, seperti bunyi, gambar, atau coretan yang membentuk kata di suatu halaman dan signified (pertanda) adalah konsep mental yang diacu pertanda (Vera, 2014).

$\begin{array}{ccc}\begin{array}{c}\text { Barthes } \\ \text { semiotik }\end{array} & \text { Saussure } & \text { kajian } \\ \text { dengan }\end{array}$
mengembangkan dua tingkat penandaan, yakni denotasi dan konotasi. Denotasi dapat diartikan sebagai makna yang "paling nyata dari tanda". Di saat yang sama, tanda denotatif adalah juga penanda konotatif sehingga konotasi merupakan makna yang subjektif. Denotasi dalam pandangan Barthes merupakan tataran pertama yang maknanya bersifat tertutup. Tataran denotasi menghasilkan makna yang eksplisit atau kentara, langsung dan pasti. Denotasi merupakan makna yang sebenar-benarnya, yang disepakati secara sosial yang rujukannya pada realitas. Tanda konotatif, di sisi lain, adalah tanda yang penandaannya mempunyai keterbukaan makna atau makna yang implisit atau tersirat, tidak langsung dan tidak pasti yang artinya terbuka kemungkinan terhadap penafsiranpenafsiran baru (Vera, 2014).

Mitos merupakan bagian dari konotasi yang sudah menguasai masyarakat yang terletak pada penandaan tingkat kedua. Konstruksi penandaan pertama adalah bahasa, sedangkan konstruksi penandaan kedua adalah mitos yang dipahami oleh Barthes sebagai metabahasa. Salah satu ciri pandangan milik Barthes, yakni penggalian lebih jauh dari penandaan untuk mencapai mitos yang bekerja dalam suatu realitas dalam keseharian di masyarakat (Kurniawan, 2001).

Dalam usaha mencari makna, peneliti mengawalinya dengan pemilihan kata pada kalimat yang menunjuk budaya lokal serta budaya global yang digambarkan dalam beberapa rubrik majalah Gogirl! (2013). Kemudian, kata yang telah dipilih dalam artikel tersebut 
dianalisis menggunakan literatur yang sesuai dengan permasalahan tersebut.

Pada tahap kedua, kata dan gambar yang sudah terpilih lalu dijelaskan bagaimana dan apa makna denotasi yang terkandung di dalamnya. Setelah itu, pada tahap ketiga, peneliti mencari makna konotatif yang terdapat dalam teks serta gambar dalam artikel yang dipilih. Makna konotasi berarti makna yang tersirat atau berarti lainnya. Akhirnya, dicari mitos yang berada dalam tingkatan konotasi. Di sini, mitos merupakan konotasi yang sudah menguasai masyarakat (Hoed, 2011).

\section{HASIL DAN PEMBAHASAN}

Pembacaan atas majalah Gogirl! dengan menggunakan pendekatan semiotik, menemukan tiga hal penting. Ketiga hal tersebut merupakan hibridisasi budaya, yang bisa dilacak dalam tiga hal pokok, yakni penggunaan bahasa, representasi budaya Eropa, dan lokal.

\section{Penggunaan Bahasa Gado-gado sebagai Strategi}

Bahasa campuran merupakan salah satu bentuk pertemuan antarbudaya yang terdapat pada majalah Gogirl! dalam mengkomunikasikan konten artikelnya. Mereka menyebutnya dengan istilah bahasa gado-gado. Ini dilakukan dengan menuliskan bahasa Indonesia dan bahasa Inggris secara bersamaan. Majalah Gogirl! sebagai majalah produk Indonesia, memasukkan unsur budaya global ke dalam artikelnya, yaitu dengan menggunakan bahasa Inggris yang ditujukan agar pembaca mengetahui serta terbiasa dengan budaya global, khususnya budaya Barat. Bahasa Indonesia dalam hal ini budaya lokal. Hibriditas pun terbentuk dalam majalah Gogirl!, yaitu dengan penggunaan bahasa gado-gado untuk penulisan seluruh artikelnya. Ini bisa dilihat, misalnya, dalam kutipan artikel berikut.

“...Walau diucapkan dalam
bahasa Inggris tapi tetep nilai
budayanya adalah budaya
Indonesia. Hanya karena kita
sampaikan dalam bahasa 'gado-
gado' tapi bukan berarti kita
nggak Indonesia Banget $:-$
Jaman sekarang saat dunia udah
nggak ada lagi batas negara, kita
harus jadi anak muda yang punya
jiwa Indonesia dengan wawasan
Internasional” ("Issue Ke-
Indonesiaan", 2013).

Secara denotatif, kalimat di atas menunjukkan bahwa majalah Gogirl! memiliki tujuan atas penggunaan Bahasa Inggris sebagai bahasa campuran dengan Bahasa Indonesia. Ini dilakukan agar pembaca mengetahui serta terbiasa dengan budaya global, khususnya budaya Barat yang menggunakan bahasa tersebut sebagai bahasa utama. Majalah Gogirl! juga menegaskan bahwa anak muda harus mempunyai jiwa Indonesia, tapi tetap harus memiliki wawasan internasional. Hal tersebut mengartikan bahwa penggunaan istilah global merupakan strategi majalah Gogirl! untuk menunjukkan ke-internasional-nya.

Majalah Gogirl! menyebut bahasa campuran ini dengan istilah bahasa gadogado seperti layaknya makanan gado-gado yang mencampurkan berbagai jenis unsur makanan menjadi satu piring. Bahasa campuran ini dapat dilihat pada artikel berjudul Cheap and Healthy Meal For A Week. Artikel tersebut menyajikan jadwal menu selama satu minggu dengan menu makanan sehat secara berbeda-beda. Menu dalam satu hari dibagi menjadi empat waktu, yaitu breakfast (sarapan pagi), lunch (menu siang hari), dinner (menu sore) atau malam hari dan juga dilengkapi dengan snack yang berisi makanan ringan ataupun pilihan minuman 
sehat. Menunya disajikan dalam campuran antara makanan lokal dan menu makanan yang identik dengan masyarakat Barat.

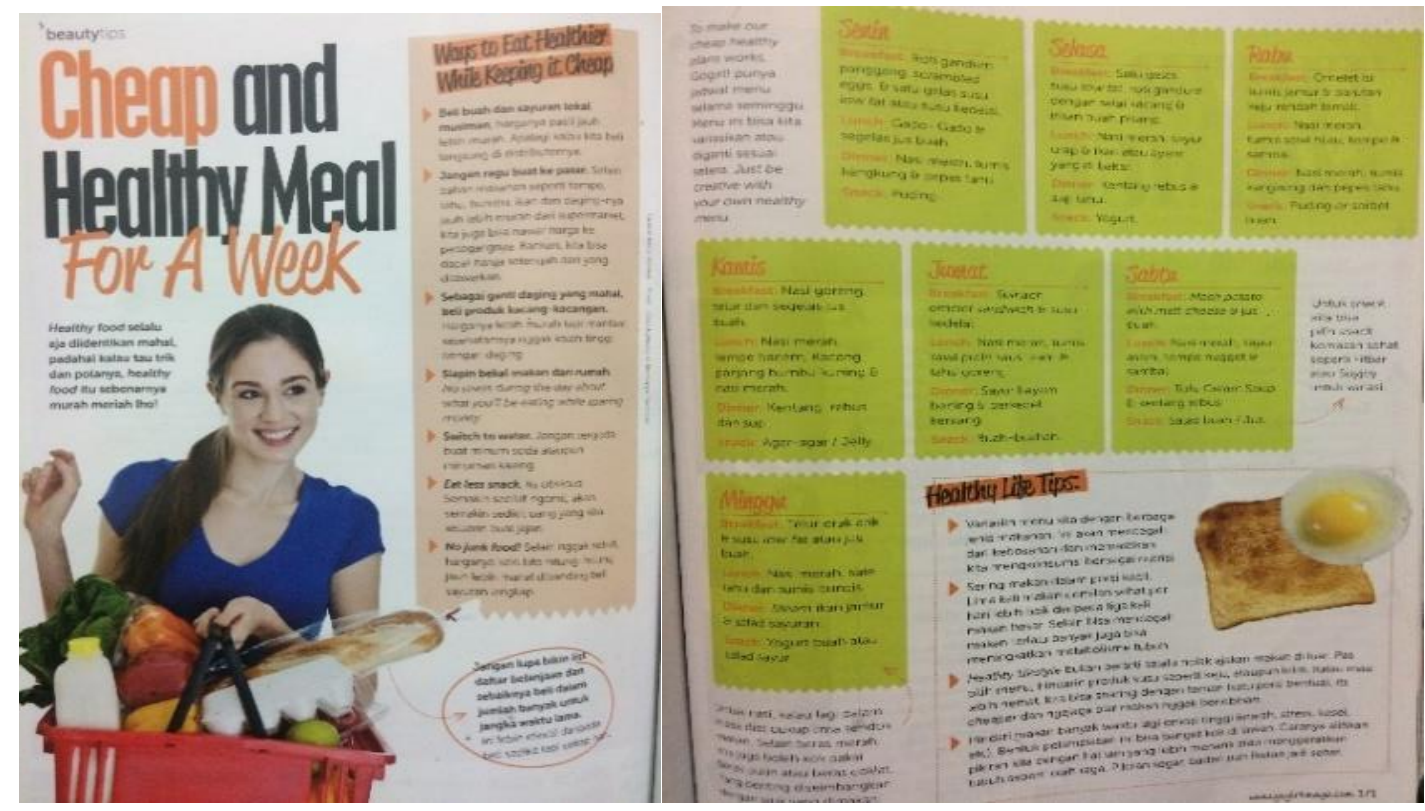

Gambar 1: Artikel Cheap and Healthy Meal For A Week. Sumber: Majalah Gogirl!.

Pada jadwal menu breakfast hari Senin tertulis menu "Roti gandum panggang, scrembled eggs, dan satu gelas susu low fat atau susu kedelai" dan "Telur orak arik dan susu low fat atau jus buah" pada hari Minggu. Dalam hal ini, terlihat bagaimana majalah Gogirl! menggunakan istilah global, yaitu menu scrambled eggs dan istilah lokal, telur orak arik, di hari yang berbeda. Padahal, scrambled eggs dalam bahasa Indonesia mempunyai arti yang sama dengan telur orak-arik. Secara konotatif, penggunaan bahasa asing, dalam hal ini bahasa Inggris, hendak menunjukkan bahwa penggunaan Bahasa Inggris merupakan bahasa asing yang kerap dan biasa digunakan oleh masyarakat Indonesia.

Bahasa gado-gado yang digunakan oleh majalah Gogirl! ini membentuk sebuah konsep "campur kode". Hal tersebut kerap menyebabkan adanya objek sama yang dituliskan dalam satu kolom artikel yang menghasilkan makna berbeda, seperti kasus scrambled eggs dan telur orak arik yang memiliki arti sama, tetapi maknanya berbeda sesuai dengan food culture yang terbentuk. Di sini, majalah Gogirl! tidak mementingkan bahwa kata tersebut merupakan suatu objek yang sama, yang terpenting adalah penggunaan bahasa Inggris dalam artikelnya. Ini merupakan usaha untuk menegaskan bahwa penggunaan bahasa Inggris ditujukan untuk meningkatkan daya tarik terhadap keseluruhan artikel yang dituliskan dalam majalah Gogirl!. Namun, sekaligus, mencerminkan sifat inferiornya sebagai masyarakat terjajah yang senantiasa melihat penjajah lebih baik. Oleh karena itu, meskipun kata dalam artikel menggunakan bahasa Indonesia 
yang telah ada padanan katanya, tapi Gogirl! tetap menggunakan bahasa Inggris.

Majalah Gogirl! juga melakukan negosiasi dengan menggunakan identitas Barat dalam tataran konten artikel lokal melalui bahasa gado-gado. Padahal, menu yang disajikan majalah Gogirl! mayoritas menggunakan unsur lokal, yaitu dengan menggunakan bahasa Indonesia serta menu makanan yang identik dengan Indonesia. Penggunaan bahasa Inggris dimanfaatkan untuk menunjang penulisan artikel agar unsur identitas lokal tidak menjadi stagnan, lebih menarik, dan artikel tetap sesuai dengan isu masa kini. Selain itu, majalah Gogirl! mencoba membangun kualitas komunikasi dengan pembaca agar terasa lebih dekat. Pada proses hibriditas ini, terlihat bagaimana budaya lokal memiliki ketergantungan atau keterikatan pada budaya global.

\section{Identitas Eropa sebagai Inspirasi}

Pada subbagian ini, pembahasan akan melihat identitas global sebagai inspirasi bagi produk lokal. Hibriditas pada majalah Gogirl! merupakan strategi untuk mempertahankan atau meningkatkan eksistensinya. Maka, Gogirl! perlu memiliki konten dengan unsur identitas global, di antaranya identitas Eropa sebagai inspirasi. Menurut Paul S.N Lee (1991), terdapat empat cara yang dapat dilakukan untuk merespons budaya global, salah satunya, sesuai pembahasan ini, adalah coral pattern. Coral pattern merupakan pola penyerapan budaya asing dengan mempertahankan bentuknya, tapi mengubah isinya, sesuai dengan karakter batu karang (coral). Contohnya, lagu yang dimainkan dengan melodi asing, tapi liriknya menggunakan bahasa lokal (Mubah, 2015).

Dalam rubrik Hair Section, identitas Eropa secara jelas diadaptasi oleh majalah Gogirl!. Dalam artikel berjudul The Ancient Greek (Yunani kuno), Gogirl! memaparkan gaya rambut Yunani Kuno, dan menyebutkan langkah-langkah dalam membentuk rambut sesuai tema. Dalam hal ini, ada tiga pilihan gaya rambut yang disarankan, yaitu Greek Tail, The Aphrodite, dan Spit Goddes. Ketiga gaya yang diaplikasikan pada model Gogirl! memiliki kesamaan bentuknya, yaitu rambut kepang atau braid dalam bahasa Inggris. Gaya rambut The Ancient Greek ini memiliki tingkat kerumitan yang tinggi. 

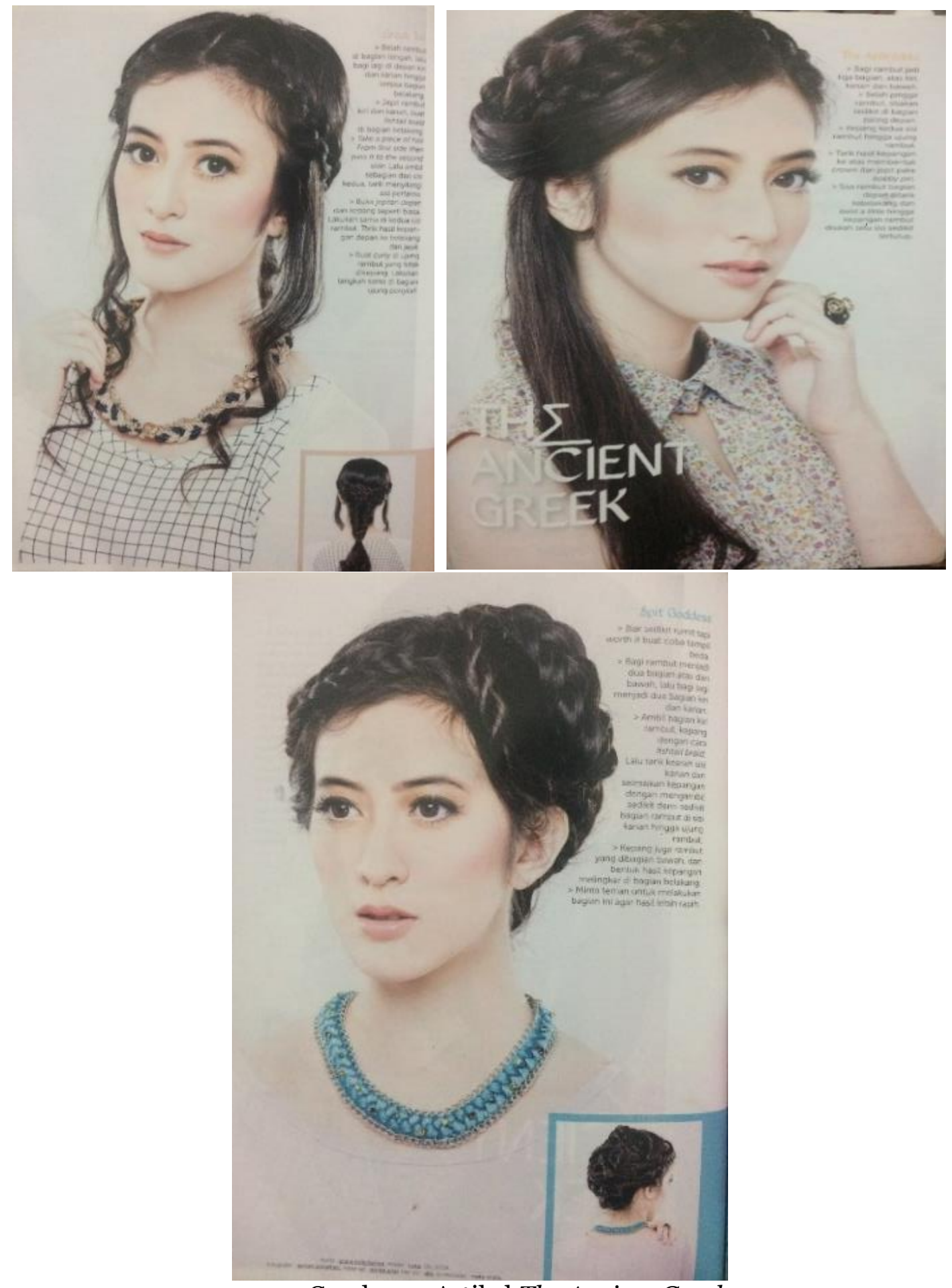

Gambar 2: Artikel The Ancient Greek.

Sumber: Majalah Gogirl!.

Makna konotasi gambar 2 menunjukkan bahwa gaya rambut ala The Ancient Greek ini tidak usang karena waktu, dan cocok untuk diaplikasikan pada remaja Indonesia. Artikel gaya rambut ala Yunani Kuno ditujukan untuk memberikan inspirasi gaya rambut remaja Indonesia.
Melalui model asal Indonesia (lokal), gaya rambut ala Yunani Kuno ini dipraktikkan. Gaya rambut kepang sebenarnya sudah lama dikenal oleh masyarakat Indonesia meskipun dengan model sederhana. Namun, melalui tampilan gambar 2, Gogirl! memberikan kesan gaya rambut 
kepang yang modern, terutama karena ia diambil dan diinspirasi dari budaya Eropa yang telah mapan.

Sejarah peradaban Yunani sendiri sudah dimulai sejak 3000 sebelum masehi. Negara ini dianggap sebagai pelopor dari berbagai bidang kehidupan, diantaranya seni drama, puisi, bahkan pengembangan ilmu pengetahuan (Sudrajat, 2010). Hal tersebut menjadi dasar bahwa Yunani merupakan negara yang juga ikut berperan dalam perkembangan benua Eropa serta menyebarkan unsur budayanya ke seluruh dunia sebagai budaya global.

Gaya rambut ala Yunani kuno ini merupakan salah satu ciri identitas masyarakat Yunani di mana gaya rambut dapat menunjukkan umur seseorang, jenis kelamin, dan posisi dalam masyarakat. Pada masyarakat Yunani Kuno, gaya rambut yang digambarkan majalah Gogirl! biasa digunakan oleh perempuan kelas atas. Ini berarti bahwa perempuan yang memiliki rambut pendek dan sederhana adalah wanita biasa atau kelas bawah. Rambut panjang yang dimiliki perempuan Yunani dibentuk seperti rambut dewi Yunani Kuno dalam bentuk kepang dan ikal. Model rambut ini biasa digunakan untuk acara-acara tertentu. Pada zaman sekarang, gaya rambut ini dijadikan sebagai inspirasi model rambut untuk menunjang penampilan agar tampak modis dan tampil beda. Model Catia, finalis kompetisi Gogirl! Look 2009, merepresentasikan gaya tersebut.

Dari analisis gambar 2, dapat dilihat bahwa hibriditas ditunjukkan melalui pola coral pattern majalah Gogirl! dengan menggunakan identitas Eropa, yaitu gaya rambut ala Yunani Kuno sebagai tema artikel dengan mempertahankan bentuk gaya rambut Yunani Kuno. Pola gaya rambut yang dibentuk pun benar-benar sama atau sesuai dengan gaya rambut yang biasa digunakan masyarakat Yunani Kuno, yang membedakannya adalah penggunaan wajah atau model tersebut. Di sini, ada unsur negosiasi yang berlangsung, yakni unsur lokal dan global. Keduanya terlihat dalam satu artikel yang membentuk suatu kesatuan konten artikel yang menarik tanpa menghilangkan unsur lokalnya, yaitu tetap menggunakan model Indonesia. Secara tidak langsung, identitas global dimanfaatkan untuk mengangkat konten lokal.

\section{Semangat Lokalisme dalam Konten Majalah Gogirl!}

Hybrid culture merupakan upaya yang dilakukan majalah Gogirl! untuk mempertahankan identitas lokal. Globalisasi menjadi penyebab identitas lokal bertransformasi dengan memasukkan identitas budaya global di dalamnya. Proses negosiasi berlangsung dengan menyandingkan kedua unsur budaya dalam satu tempat. Salah satu upaya untuk membuat identitas lokal tetap bertahan dalam majalah Gogirl! dengan menyandingkannya dengan identitas global.

Artikel berjudul Cheap and Healthy Meal For A Week pada kolom Ways to Eat Healthier While Keeping it Cheap menjelaskan bahwa dalam mengkonsumsi makanan sehat disarankan menggunakan bahan makanan lokal yang murah dan terjangkau. Ini bisa dilihat pada artikel berikut. 


\section{Ways to Eat Healthier While Keeping it Cheap}

Beli buah dan sayuran lokal musiman, harganya pasti jauh lebih murah. Apalagi kalau kita beli langsung ke distributornya.

Jangan ragu buat ke pasar. Selain bahan makanan seperti tempe, tahu, bumbu, ikan, dan daging-nya jauh lebih murah dari supermarket, kita juga bisa nawar harga ke pedagangnya. Bahkan, kita bisa dapat harga setengah dari yang ditawarkan.

Sebagai ganti daging yang mahal, beli produk kacang-kacangan. Harganya lebih murah tapi manfaat kesehatannya nggak kalah tinggi dengan daging.

Siapin bekal makan dari rumah. No stress during the day about what you'll be eating while sparing money.

Switch to water. Jangan tergoda buat minum soda ataupun minuman kaleng.

Eat less snack. Its obvious. Semakin sedikit ngemil, akan semakin sedikit uang yang kita keluarin buat jajan.

No junk food! Selain nggak sehat, harganya kalo kita hitung-hitung jauh lebih mahal dibanding beli sayuran (Banea, 2013).

Makna konotasi dalam artikel Ways to Eat Healthier While Keeping it bahwa makanan sehat itu mahal, dan mayoritas diolah dalam menu makanan ala barat. Majalah Gogirl! mencoba menampilkan makanan sehat berupa makanan lokal dengan harga murah dan terjangkau. Dalam kaitan ini, majalah Gogirl! berupaya mengubah stereotip makanan sehat sebagai makanan lokal. Upaya tersebut dimulai dari tips mencari bahan makanan sehat yang berorientasi pada makanan lokal, sampai pada jadwal menu makanan yang disediakan dengan menyarankan beberapa menu makanan lokal pula. Semua hal yang mengarah pada unsur lokal, terlihat adanya upaya yang dilakukan untuk mempertahankan unsur identitas lokal dengan beberapa cara tersebut. Ini terungkap dalam kalimat, "Beli buah dan sayuran lokal musiman, harganya pasti jauh lebih murah. Apalagi kalau kita beli langsung di distributornya" (Banea, 2013). Kalimat tersebut menunjukkan bahwa sebaiknya membeli buah dan sayuran lokal karena lebih murah. Pada kalimat pertama, secara spesifik, disebutkan kata "lokal" dan "musiman" yang menegaskan macam buah dan sayuran yang disarankan. Hal ini berhubungan dengan pembahasan mengenai food culture. Makanan merupakan produk budaya. Buah dan sayuran lokal murni hasil panen masyarakat daerah yang ada di Indonesia dan terjadi secara "musiman". Ini berarti bahwa masa panen setiap buah dan sayuran terjadi pada musim tertentu dengan waktu yang berbeda-beda.

Kata "pasti" pada kalimat selanjutnya setelah koma, memiliki arti sudah tetap, tidak boleh tidak, tentu dan mesti. Kata "pasti" menegaskan bahwa buah dan sayuran lokal memang lebih murah, sehingga kata "pasti" ini ditujukan untuk meyakinkan pembaca dengan mendukung kalimat pertama, yaitu "Beli buah dan sayuran lokal musiman" yang saling berhubungan. 
Jangan ragu buat ke pasar. Selain bahan makanan seperti tempe, tahu, bumbu, ikan, dan daging-nya jauh lebih murah dari supermarket, kita juga bisa nawar harga ke pedagangnya. Bahkan, kita bisa dapat harga setengah dari yang ditawarkan (Banea, 2013).

Poin kedua menjelaskan bahwa jangan ragu untuk membeli bahan makanan ke pasar karena lebih murah dibandingkan ketika membeli di supermarket. Pasar yang dimaksudkan adalah tempat belanja yang merujuk pada pasar tradisional. Pasar modern seperti supermarket identik dengan pasar ala barat yang mendunia melalui globalisasi. Supermarket menjual barang-barang produk lokal dan impor. Sebaliknya, barang impor di pasar tradisional lebih langka atau setidaknya lebih jarang ditemukan. Melalui perbandingan tersebut, majalah Gogirl! menyarankan untuk membeli bahan makanan di pasar yang merujuk pada pasar tradisional. Pasar tradisional berkaitan dengan identitas lokal masyarakat Indonesia yang identik dengan harga yang lebih murah.

Upaya yang sama juga dapat dilihat pada artikel Fun Games Now and Then. Artikel ini menunjukkan adanya proses negosiasi yang berlangsung melalui perbandingan seperti yang terdapat pada analisis artikel sebelumnya, yaitu lewat permainan tradisional yang memiliki lebih banyak manfaat dibandingkan permainan modern. Pada kolom terakhir, Irreplaceble Traditional Games, juga menjelaskan bahwa permainan tradisional sebenarnya tidak punah atau hilang tersaingi oleh permianan modern yang tren saat ini. Fakta yang dituliskan menunjukkan bahwa permainan tradisional masih ada saat ini. 


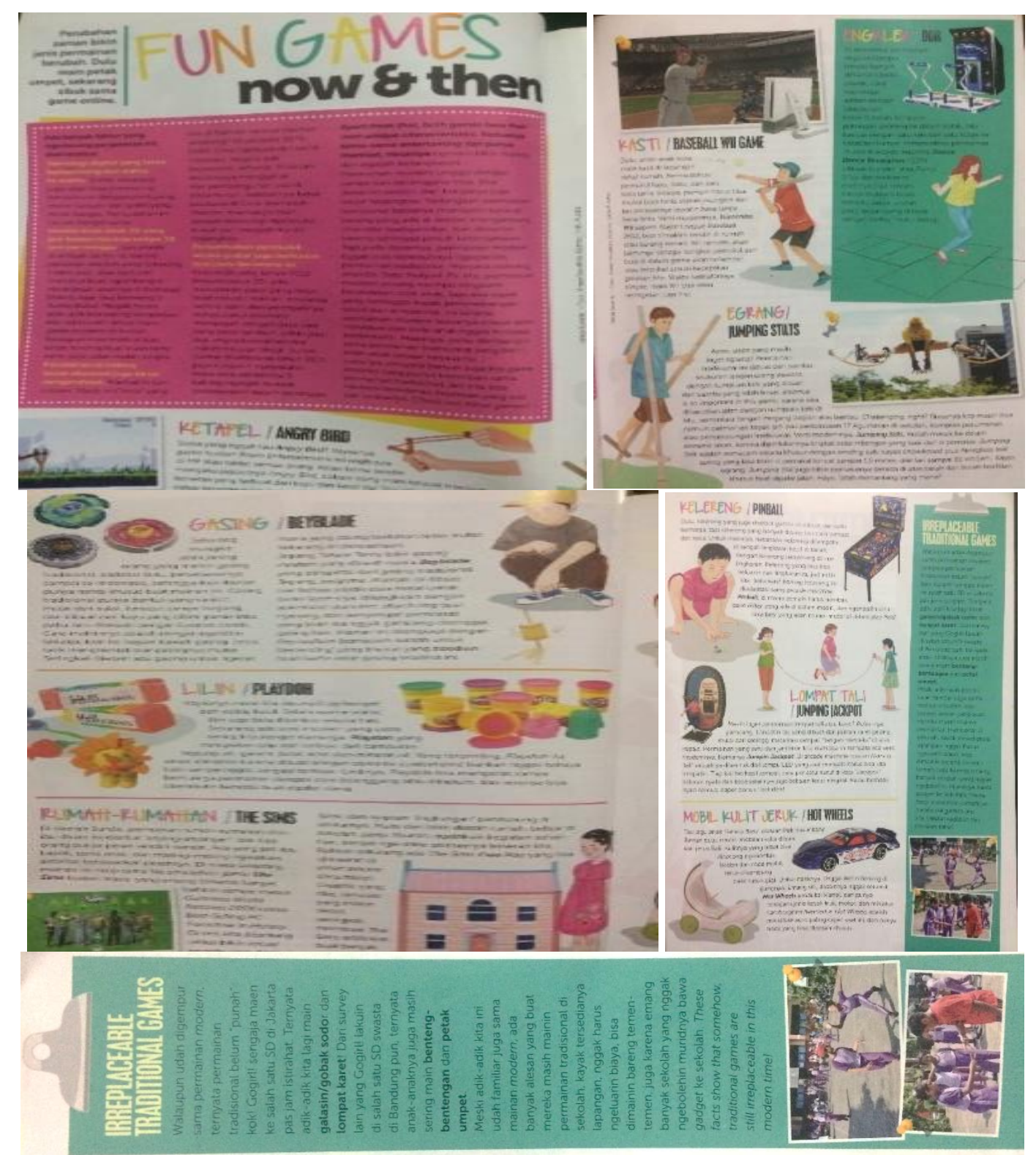

Gambar 3: Artikel Fun Games Now and Then.

Sumber: Majalah Gogirl!.

Berdasarkan narasi yang terdapat dalam artikel tersebut, tersirat makna bahwa majalah Gogirl! berpihak pada permainan tradisional yang dinilai lebih baik dari permainan modern dengan menyebutkan beberapa manfaat yang dihasilkan. Ada kalimat ajakan yang ditujukan pada pembaca agar tetap memainkan permainan tradisional walaupun berada pada zaman yang dipenuhi oleh teknologi serba canggih.

Keberpihakannya terhadap permainan tradisional terlihat melalui dua kalimat sanggahan yang ditujukan pada permainan modern pada kalimat kelima dan keenam yang keduanya menggunakan kata "tapi". Pada kalimat kelima, yaitu "Tapi pada dasarnya, permainan modern gabisa sepenuhnya ngegantiin permainan tradisional”, dan pada kalimat keenam, yaitu "..permainan modern emang mampu ningkatin kecerdasan otak anak, tapi ada aspek yang tertinggal kayak perkembangan sosial dan emosional". Kata "tapi” adalah sinonim dari kata "tetapi” yang termasuk dalam kata penghubung konjungsi 
adversatif. Konjungsi adversatif menurut Achmad HP adalah pertalian perlawanan yang bermakna mempertentangkan suatu hal, keadaan atau perbuatan dengan hal, keadaan, atau perbuatan dengan hal, keadaan atau perbuatan lain (Setiawati \& Pratiwi, 2016).

Keduanya sama-sama mempertentangkan bahwa permainan modern tidak dapat menggantikan permainan tradisional. Kolom terakhir juga menegaskan bahwa permainan tradisional merupakan inti dari penulisan keseluruhan artikel yang merupakan kesimpulan dari keseluruhan tulisan yang ingin disampaikan oleh Gogirl! untuk pembacanya yang ditarik dari keseluruhan tulisan dalam artikel. Penulisan juga disertai bukti dan fakta sehingga menjadi penguat bagi kesimpulan yang dituliskan. Majalah Gogirl! mencoba meyakinkan pembacanya bahwa permainan tradisional memiliki manfaat yang lebih besar daripada permaianan modern, sehingga terlihat adanya semangat lokalisme yang ditampilkan pada majalah ini.

Berdasarkan analisis di atas, dapat disimpulkan bahwa budaya global, yaitu identitas budaya Barat secara luas sudah memasuki ruang-ruang kehidupan masyarakat lokal. Budaya Barat dalam hal ini diintepretasikan mempunyai kualitas dan kuantitas yang tinggi serta kerap diposisikan sebagai pihak superior dibanding dengan budaya lokal. Pada akhirnya, budaya barat menjadi budaya dominan yang dapat mempengaruhi masyarakat dalam melihat budayanya sendiri. Hal ini menyebabkan kurangnya rasa percaya diri terhadap budaya lokal. Pada dasarnya, konstruksi yang terbentuk di masyarakat menyebutkan bahwa kultur global dianggap paling menjanjikan masa depan dengan segala macam modifikasi dan komersialisasi, sementara struktur lokal dianggap stagnan (Qodir, 2010). Citra yang tertanam pada identitas barat ini yang mengakibatkan suatu masyarakat Indonesia merasa dirinya inferior dari barat sebagai pihak superior. Superioritas identitas barat dalam majalah Gogirl! ditunjukkan melalui penulisan konten menggunakan bahasa Inggris serta tematema global digunakan sebagai inspirasi pada konten majalah Gogirl!. Meskipun demikian, budaya global dalam majalah Gogirl! tidak sepenuhnya menyingkirkan budaya lokal dalam kontennya. Menurut konsep hybrid culture Homi Bhabha, identitas lokal adalah suatu subjek atau berada pada kondisi terjajah. Perlawanan yang terdapat dalam majalah Gogirl!, yaitu dengan menerima identitas barat dan dimanfaatkan untuk kepentingan identitas lokal. Ini dilakukan majalah Gogirl! dalam hampir keseluruhan artikel yang disajikan dalam rubriknya.

Hibriditas yang terjadi merupakan suatu negosiasi antara identitas lokal dengan identitas global. Identitas lokal tetap ditampilkan sehingga semangat lokalisme masih bisa ditemukan. Superioritas identitas global dalam hal ini dimanfaatkan sebagai bentuk untuk menampilkan serta mengangkat identitas lokal pada konten yang dibahas. Dengan demikian, hibriditas konten majalah Gogirl! merupakan suatu bentuk negosiasi dari identitas lokal agar tetap eksis.

\section{KESIMPULAN}

Berdasarkan analisis konten majalah Gogirl! edisi 2013 khususnya artikel Cheap and Healthy Meal For $A$ Week, Fun Games Now and Then dan The Ancient Greek, peneliti menyimpulkan bahwa majalah Gogirl! yang didominasi oleh identitas barat, tetap mengusung unsur identitas lokal. Dengan demikian, majalah Gogirl! sebagai produk hibriditas berupaya untuk melakukan negosiasi. Identitas barat yang terlihat mendominasi dan memiliki eksistensi tinggi, 
memberikan jalan bagi budaya lokal untuk menampilkan identitasnya. Hal tersebut merupakan sebuah strategi untuk mempertahankan identitas lokal dalam tataran global. Lewat pemakaian bahasa gado-gado dan menjadikan identitas barat sebagai inspirasi, unsur-unsur barat digunakan sebagai penunjang konten artikel agar menjadi menarik.

Identitas lokal digambarkan tidak "menyerah" oleh intervensi unsur-unsur barat/global, tapi justru berperan aktif mengikuti perkembangan zaman, dan menyiasatinya melalui hibriditas. Ini dilakukan melalui semangat lokalisme dengan memasukkan atau menggunakan identitas lokal sebagai tema dalam artikelnya bersamaan dengan unsur identitas global. Superioritas masyarakat barat dalam hal ini tidak sepenuhnya menghilangkan eksistensi identitas lokal. Hibriditas justru memberikan peluang bagi budaya lokal untuk menampilkan identitasnya. Dengan demikian, resistensi tidak melulu dilakukan dengan penolakan atas budaya lain, tapi juga lewat penerimaan, yang lalu justru dimanfaatkan oleh identitas lokal untuk tetap bertahan.

\section{DAFTAR PUSTAKA}

Banea, G. K. (2013). Cheap and healthy meal for a week.

Bhabha, H. K. (1994). The location of culture. Routledge.

Christomy, T., \& Yuwono, U. (2004). Semiotika budaya. Pusat Penelitian Kemasyarakatan dan Budaya Direktorat Riset dan pengabdian pada Masyarakat Universitas Indonesia.

Demartoto, A. (2020). The representation of hybrid identity through performance and symbol of transgender santri resistance at $\mathrm{Al}-$ Fatah islamic boarding school of Yogyakarta, Indonesia. Society, 8(1), 147-162.

https://doi.org/10.33019/society.v8i 1.167

Dukut, E. M. (2019). The local-global innovation of an Indonesian toefl-like game: A cultural hybridity model. English Review: Journal of English Education, 7(2), 55. https://doi.org/10.25134/erjee.v7i2.1 605

Gogirl! (2013). Issue ke-Indonesiaan.
Hoed, B. H. (2011). Semiotik dan dinamika sosial budaya (2rd ed.). Komunitas Bambu.

Huddart, D. (2006). Homi K. Bhabha. Routledge Taylor \& Francis Group.

Ibrahim, I. S., \& Akhmad, B. A. (2014). Komunikasi dan komodifikasi: Mengkaji media dan budaya dalam dinamika globalisasi. Yayasan Pustaka Obor Indonesia.

Ida, R. (2014). Metode Penelitian Studi Media dan Kajian Budaya. Kencana.

Inkiriwang, A., \& Inkiriwang, R. E. (2014). Cultural hybridity towards an upward mobility: Implications of the american media and american corporate culture in Indonesia. Rubikon, 1(2), 1-16.

Kurniawan. (2001). Semiologi roland barthes. Yayasan Indonesia Tera.

Mubah, A. S. (2015). Isu-isu globalisasi kontemporer. Graha Ilmu.

Nilan, P., \& Feixa, C. (2006). Global youth? hybrid identities, plural worlds. Routledge. 
Qodir, Z. (2010). Muhammadiyah studies: Reorientasi gerakan dan pemikiran memasuki abad kedua. Kanisius.

Ritzer, G. (2006). Mengkonsumsi kehampaan di era globalisasi. Universitas Atma Jaya.

Setiawati, S., \& Pratiwi, H. A. (2016). Aspek kohesi konjungsi dalam wacana opini pada majalah TEMPO dan implikasinya terhadap pembelajaran bahasa Indonesia. Jurnal Gramatika, 1(1), 45-56.

Sudrajat. (2010). Yunani sebagai icon peradaban barat. Istoria, 8(1).

Surahman, S. (2013). Dampak globalisasi media terhadap seni dan budaya Indonesia. Jurnal Komunikasi, 2(1), 29-38.

Tumanggor, R., \& Ridho, K. N. (2017). Ilmu sosial dan budaya dasar. Kencana.

Usman, R. (2006). ORIENTASI: Majalah pembinaan dan pengembangan hukum \& kemasyarakatan no.4 tahun XXXIII. Fakultas Hukum Universitas Lambung Mangkurat.

Vera, N. (2014). Semiotika dalam riset komunikasi (R. Sikumba). Ghalia Indonesia. 